\title{
DEVELOPMENT OF THE TRUST ISSUE IN THE MOVIE RAYA AND THE LAST DRAGON
}

\author{
Sri Wulan ${ }^{1}$, Nur Latifah ${ }^{2}$, Sofia Sahana Sitorus ${ }^{3}$ \\ Universitas Islam Sumatera Utara, Medan, Indonesia \\ Universitas Islam Sumatera Utara, Medan, Indonesia \\ Universitas Islam Sumatera Utara, Medan, Indonesia
}

sriwulan@sastra.uisu.ac.id

Submitted:31/07/2021

Accepted: 4/08/2021

Publication: 4/08/2021

\begin{abstract}
The study discusses the development of Raya's trust issue in the movie. The qualitative method is applied to analyze the data in this study. The result shows that the protagonist in the film suffers from trust issues. There are two reasons to trigger her trust issue. T. Her friend betrays her. Her friend and her people try to steal her village's gem. This hurt the protagonist. This protagonist makes her start hard to trust anyone else. Next is trauma. Losing her village, Kumandra leaves her traumatic. She begins to show signs of trust issues. Some signs of her trust issue are overprotective toward Sisu, her beloved dragon, being wary, and keeping distance from others. The protagonist expresses such characters. She fears something terrible which can happen to Sisu. Therefore, she never trusts other people around her. She also distances herself from other people because of wariness. Sisu sees this. Sisu thinks that such a trust issue will make Raya in trouble. Finally, Sisu tries hard to teach Raya to trust other people. They eventually succeed in building Raya's trust in others, and then a magical work happens as the impact of her trust.
\end{abstract}

Keywords - Trust, trust issue, distruts, Raya, social psycology,

\section{Introduction}

Trust is an expectation or positive expectation of trustworthy and alive others in our lives, which belief is usually built through open communication without restriction by helping to understand it properly. Worchel (in Lau \& lee, 1999) himself revealed that trust is an individual's willingness (willingness) to hang himself on to others at a specific cost. Trust cannot be built quickly in the blink of an eye. Belief itself can be rational and irrational. Trust gives humans a high perspective on reality and provides a basis for decision-making and attitude toward the object itself.

Putting more trust in others can take a high risk if we are wrong in choosing that person and begin to lose confidence in others. It can happen because the one who is given the trust acts in the unexpected or out of hope. The problem of losing faith in others can take a toll on the psyche and begin to suspect distrust of people around them, or what to call trust issues.

Trust issues are trust problems with fear of betrayal, neglect, and manipulation of others. It usually accompanies some negative thoughts, such as assuming that these people are inclined toward harm. This excessive skepticism usually causes trust issues in people who begin to feel unsure and have difficulty trusting those around them. Trust issues impact itself, which results in unhealthy social relationships, which is starting to distance people and causing them to run, lowering confidence and becoming possessive. An individual might be prone to 
overthinking, dwelling on belief, or lacking faith in thinking deeply about avoiding and risk everything he felt had not happened.

The movie Raya And, The Last Dragon, is about the loss of the people's trust in Kumandra village because of one crystal ball. They assume that the ball will bring great wealth to the tribal heart. And it splits into five sections - heart, fang, tail, and tail. In this situation, Raya, the protagonist, has lost such a huge of trust in others. She fears being betrayed by others.

Thus, this study discusses the development of the trust issue problem in the movie. The protagonist begins to lose her trust, and at that time trust issue increases in the film. Her faith is reawakened by Sisu (the last dragon). Sisu teaches Raya the positive influence of belief. To destroy her trust issue, Sisu takes a long time to convince Raya again. This study focuses on developing the trust issue and the solution to the problem in the movie.

\section{Literature Review}

Thielmann and Hilbig (2015) define interpersonal trust as a risky choice of making oneself dependent on the actions in a situation of uncertainty, based upon some expectation of whether the other will act in a benevolent fashion despite an opportunity to betray. This definition includes all core components identified in earlier research (i.e., uncertainty, risk, expectation, and vulnerability towards betrayal). Still, it extends these definitions by incorporating the diverse perspectives found in different scientific disciplines. Trust is a complex condition because someone does not know the motive and the intention of others (Sally in Soesanto et al. (2013)

Trust is the act of placing confidence in someone or something else. It is social superglue. It is the binding for the most profound love, the strongest friendships, and the world's communities. Modern society is built on trust, and in the absence of trust, fear rules. With this in mind, it is easy to understand how people with trust issues might have difficulty engaging in specific social contexts and leading the most fulfilling life they can. Some of the most common settings in which individuals display a lack of trust are interpersonal relationships (romantic or otherwise), business dealings, politics, and even the use of technology. And with these different facets of life becoming increasingly interconnected, mistrust could conceivably spread from one part of a person's life to another. (Goodtheraphy.org, 2014)

Trust is a fundamental human experience. It is necessary for society to function. It can play a significant role in happiness. Without it, fear rules. Trust is not an either/or proposition but a matter of degree. Some life experiences can impact a person's ability to trust others. Everyone has uncertainty about whom to trust and how much. It is not always clear when trust is appropriate. People make choices about whom and how much to charge every day. We are more willing to trust at some times than others. That is a good thing. A total lack of mistrust would be a severe problem. But judgments about when and whom to trust help keep us safe and alive.

Trust issues often come from early life experiences and interactions. These experiences usually take place in childhood. Some people do not get enough care and acceptance as children. Others are abused, violated, or mistreated. These things may lead to difficulty trusting as an adult. (Zak et al., 1998).

Trust and risk are complementary terms in social relations. An emphasis on risk is generally based on mistrust, whereas trust is associated with fewer doubts about security. Those who trust others do not look for high security before they act.

Trust is related to reliability of the information, which may reduce insecurity, and this is visible in the following definition: Trust is a "reliance upon information received from another person about uncertain environmental states and their accompanying outcomes in a risky situation" (Schlenker/Helm/Tedeschi in Bierhoff, H. \& Vornefeld, B. (2004)).

Trust is a feeling that could be defined as a belief, faith, or hope in a person, place, or thing. Trust issues expand beyond relations in one's personal life. It makes sense that people would 
have doubts about our government systems and politics in general due to all the controversies and conspiracies that exist today. (Lewis, 2013)

As society becomes increasingly complex and resources become scarce, cooperation becomes a necessity. Cooperation requires trust. But trust is risky as it requires us to be vulnerable and open about our needs and outcomes. This vulnerability is something everyone grapples with since achieving goals alone is sometimes impossible (Popova, 2014).

Thus, matters of trust influence all areas of our life. Dr. David DeSteno says, "The heart of trust is vulnerability. There's something that you need to acquire or achieve, and you need help to do it, but by accepting that help, you make yourself vulnerable" (Weir, 2013).

This means that everyday cooperation and communication are fraught with risks and the possibilities of betrayal. Risk becomes part and parcel of our choice to trust. Humans are generally risk-averse and are biased to protect themselves against loss. But, according to DeSteno, "the potential benefits from trusting others considerably outweigh the potential losses on average" (Weir, 2013).

In spite of the potential risks, trust helps simplify and reduce social complexity. It transforms "objective uncertainty into subjective certainty" (Bierhoff \& Vornefeld, 2016). However, the issue of 'whom' to trust remains a dilemma. Researchers have tried to understand how we decide whom to trust.

We also use "indirect reciprocity," i.e., we learn from a peer's experience to decide whom to trust. This is trust based on reputation. If a lousy reputation clouds a person, then we are alert and more protective of our interests. This leads to another byproduct, i.e., the shadow of the future, the fear of accruing damage to social capital by behaving in ways that lead to a negative reputation (Popova, 2014).

Trust issues are characterized by fears of betrayal, abandonment, and manipulation. Many of us have these feelings - whether we have trouble trusting our boyfriends and girlfriends, our parental figures, or even our doctors. These typically stem from a somewhat traumatic event. Maybe you had a similar or equally traumatic experience, but you are not sure if it necessarily resulted in trust issues. Here are several signs that you have trust issues (Bennett, 2017):

1. You assume betrayal. You believe someone has betrayed your trust even if you have no rightful reasoning.

2. You await betrayal. You assume someone will betray you in due time, despite how honest they have been in the past.

3. You are overly protective. You are very protective of your loved ones out of fear that they will become disloyal.

4. You distance yourself from others. You decide it's best to limit your relationships to avoid fears of betrayal or abandonment.

5. You avoid commitment. No matter how much you care for someone, you refuse to commit yourself to him or her.

6. You don't forgive the minor mistakes. You make a big deal out of nothing, and it's the end of the world if someone makes the slightest mistake.

7. You are excessively wary of people. Everybody you meet is extremely cautious and suspicious of.

8. You feel lonely or depressed. Your fears have led you to isolate yourself from others and enter a state of depression.

\section{Research Method}

The qualitative method is applied in this study. By using such qualitative method, a program, an event, an activity, a process, or one or more individuals is explored in-depth" (Creswell, 2003:15). This method is used as a problem-solving procedure by describing the facts 
used in films. The analysis is about the character affected by trust issues and other significant impacts on the development changes of the affected surface. And in the aggregation, we have found two characters as affected by the trust issue.

\section{Results and Discussion}

The following data shows the research finding of the growth of Raya's trust issue.

\section{a. Trigger of Raya's Trust Issue}

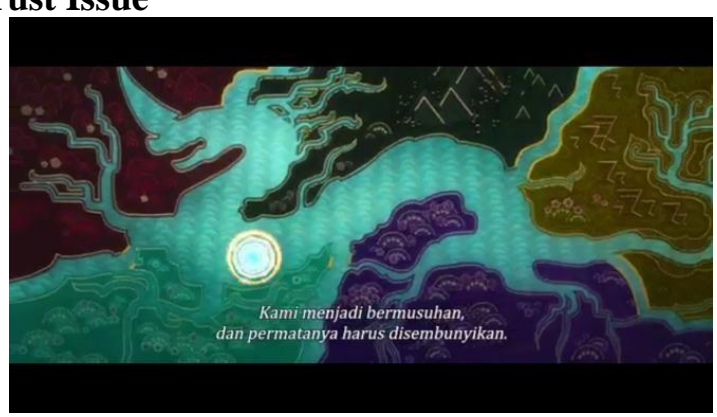

(00:02:55)

The teachings and history that Raya has known since she was a child from the surrounding environment are one of the reasons why Raya has difficulty trusting another land. At $02.36-02.50$, it is told that the dragons sacrifice themselves as a result of eradicating the Druun, and all that was left was a Sisu's Gem. The humans should have been united after Sisu and the dragons try to fix everything, but the humans are defeated by their selfishness and scrambled to get the remnants of the magic of the last dragon. Kumandra is divided, and each land is hostile to the other. Based on clinical research, it is concluded that children learn to distrust their perceptions in social interactions when they have been confused and mystified by double messages experienced in their family.

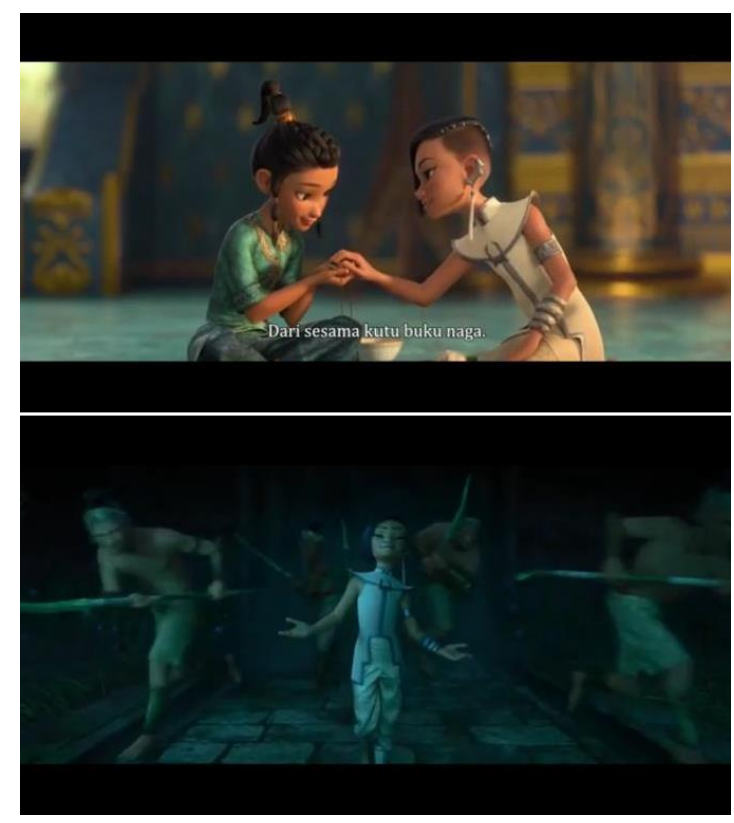

(00:14:50) (00:16:30)

During the event to host countries that come to the Land of Heart, Raya befriends Namaari (Princess of Fang). Raya thinks Namaari is a good friend for giving Raya a gift. Then, she shows Namaari Sisu's Gem, and it turns out that Namaari's good attitude is the Land of Fang trap to steal Sisu's Gem. Having been cheated and betrayed, this incident becomes the beginning and the main reason for Raya's complete loss of trust in others. She has trusted Namaari as her 


\section{IJEAL (International Journal of English and Applied Linguistics)}

Volume : 1 | Number 2 | August 2021 | E-ISSN : 2787-9482 | DOI: doi.org/ijeal.v1n1.1042

best friend. Namaari betrays their friendliness. This hurts Raya, and she begins to distrust others. It can be seen that betrayal can be the trigger of trust issues.

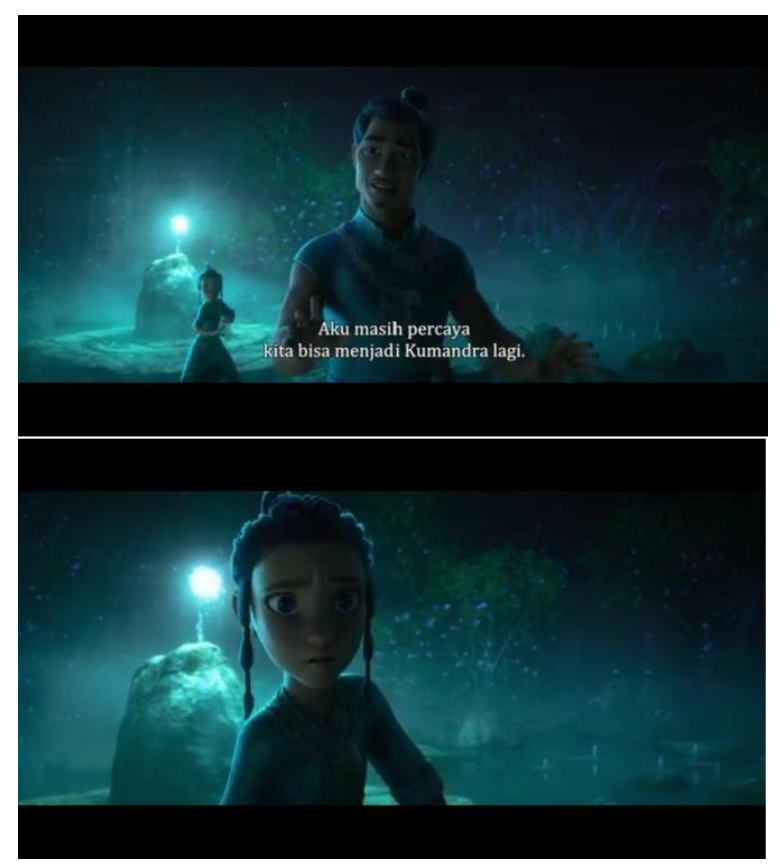

(00:17:30)- (00:17:37)

Raya's Father: I still believe we can be Kumandra again.

After Raya and her father are cornered by another land that wants to steal Sisu's Gem, Raya's father says something unexpected to quell the other land's greediness. But Raya's expression shows that she is shocked and disbelieving of her father's statement.

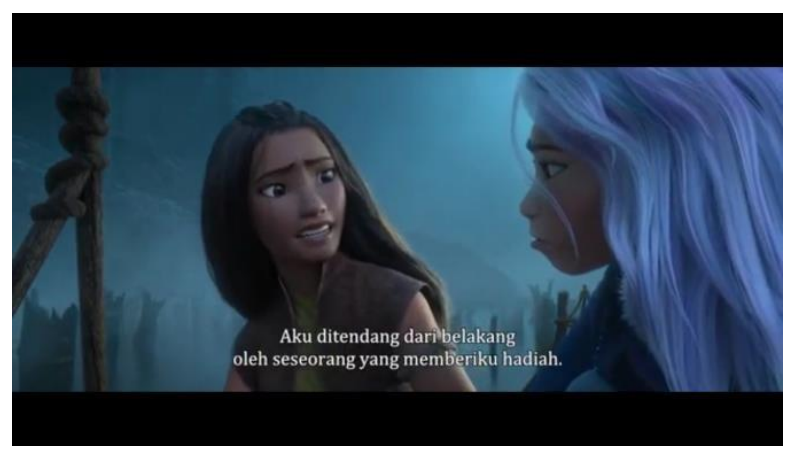

(00:54:35)

Raya: ... And you know what happen?

I get kicked in the back by someone who gives me a gift.

This incident is a trauma that remains in Raya's memory. Even after six years, Raya talks to Sisu. She still memorizes the event. She remembers being betrayed by her friend and the loss of her village. This is the beginning $f$ Raya's trust issue. The incident leaves her a trauma. 


\section{b. Raya's Life with Trust Issue}

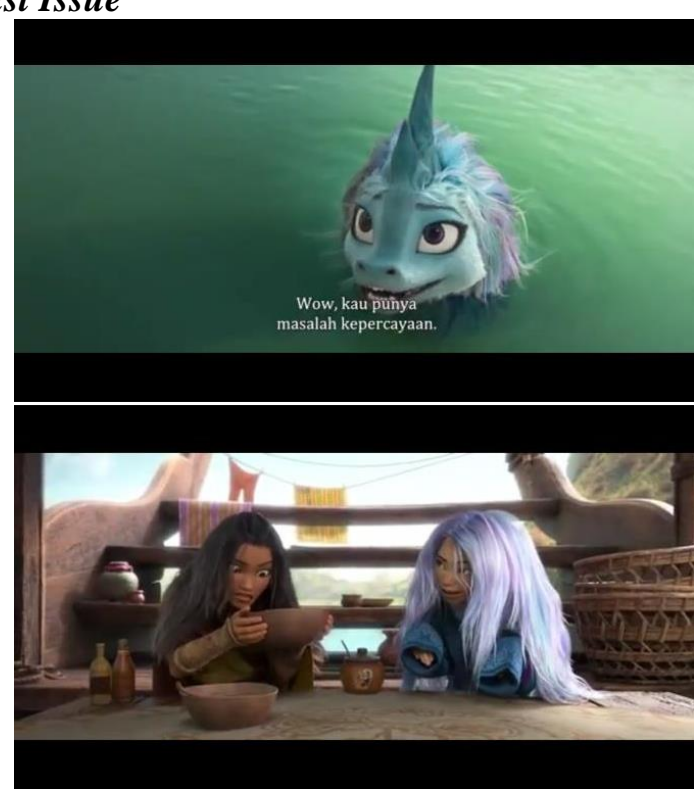

(00:38:47) (00:39:19)

Raya : Sisu, I saw people lose theirmind for a dragon gem.

Can you imagine what will they do overan actual dragon?

We need you to make this all work!

Until we have all the gem you have to stayhuman, please

Sisu : Wow, you've really got sometrust issue.

Raya : Look, my father blindly trustedpeople. Now, he's stone.

------

Sisu : What are you doing?

Raya : We don't know! It could bepoisoned!

Sisu :Why would he poisoned us?

After being chased by the Fang people, Raya, Sisu, and TukTuk fled aboard the Boun ship. Boun is a talkative boy, but he does not look dangerous. Yet, Raya always keeps her guard and is suspicious of Boun, making Sisu realize that Raya suffers from a trust issue. But, Raya justifies her action after what happens to his father. When Boun serves their meal, Raya keeps getting suspicious and overly cautious with the meal. She instead eats with her not-sogood snack, a jerky. Raya refuses to at what has been served by Boun. This happens because she distrusts anyone.

This shows her wariness of people. She is overly cautious and her overprotectiveness of Sisu, as she regards Sisu as essential for her.

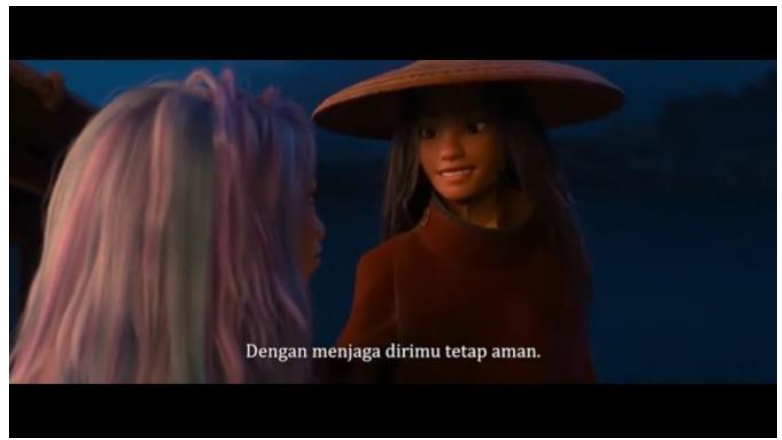


Raya : Sisu, I think maybe it's saver foryou to stay here, on the boat

Sisu : What??

Raya : Without you we can't put the gemtogether

Sisu : But, I wanna help

Raya : I know, and you will, by stayingsave.

I'll be back before you know it

After they arrive in the Land of Talon, Raya plans to sneak her way to the Chief of Talon and grab the gem piece. But, she does not allow Sisu to follow her because it is a saver for Sisu if she stays on the boat.

This situation also shows her over-protectiveness toward Sisu. She avoids the fact that Sisu is a dragon stronger than humans.

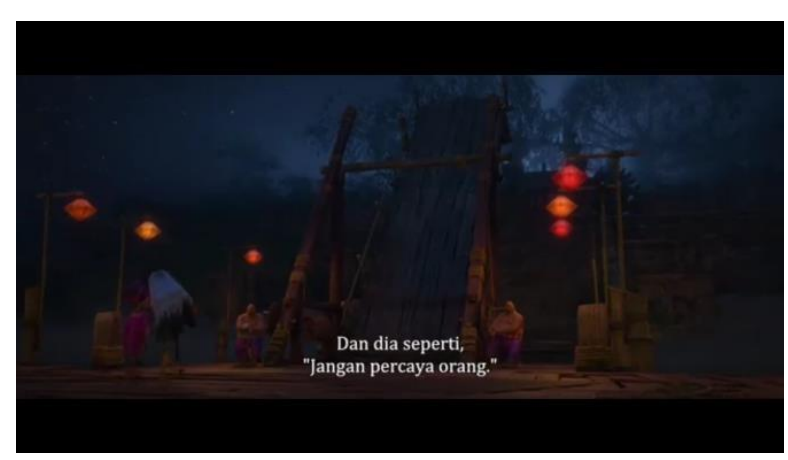

Sisu :See?

$(00: 49: 13)$

That's what I've been trying to tellmy girl, Raya.

And she's like "don't trust people" "don't talk to anyone"

Eventually, Sisu gets off the boat and goes into the town. There she gets to know an old lady that knows where Chief Dang Hai is. Sisu asks the old lady to lead the way. But, the old lady is lying and leads Sisu out of the town's gate with many Druun.

Raya always reminds Sisu not to trust anyone and not to talk to anyone. This also shows her overprotectiveness toward Sisu and her desire to distance herself from others as she reminds Sisu not to speak to anyone.

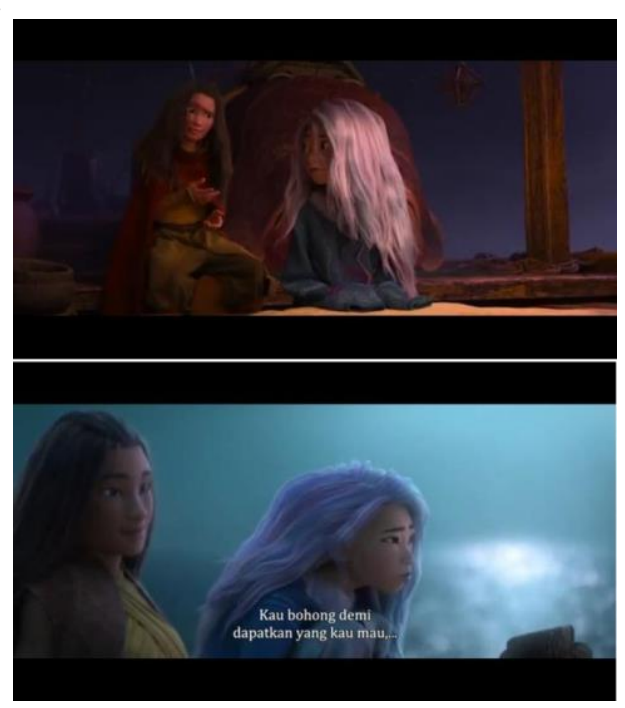


(00:51:00)

Sisu : I can't believe it, that old lady wasreally gonna to hurt me...

Raya : Well, I'm sorry Sisu, but that's how the world is now. We can't trust anyone.

Sisu : being people is hard

Sisu : ... You lie to get what you want.Like the talon chief back there.

Raya : Yeah, the world is broken. Youcan't trust anyone.

Sisu : Or maybe the world is broken because you don't trust anyone.

Raya : You sound just like my Ba.

Sisu : He sounds like a smart man.

Raya: Yeah, he was. I really wanted to believe him..I really want to believe that we can be Kumandra again.

Sisu : Then we can.

After being saved by Raya and took the Dragon Gem Piece, they continue their journey to the Land of Spine. On the way, Sisu laments at her bad experience that got a sarcastic reply from Raya.

Based on Bennet, Raya already has three signs of trust issues. She is overly protective, worried about people, and she also distances herself from others. This situation proves that she suffers from trust issues.

\section{c. Sisu teaching Raya to Trust Again}

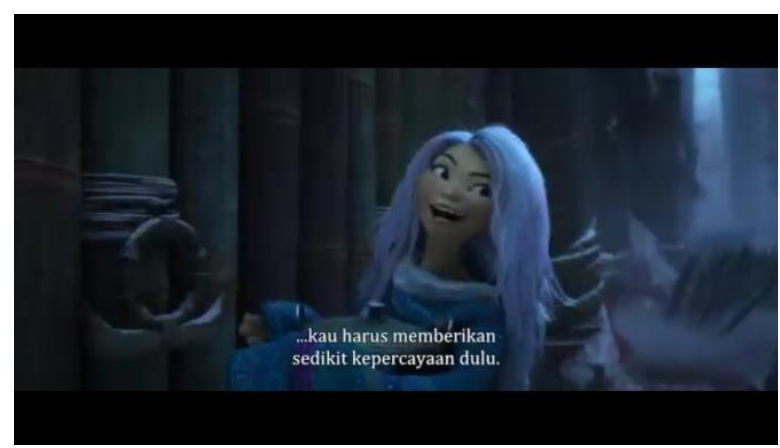

(00:55:38)

Raya : Sisu, come back, please! What areyou doing ?!

Sisu : I'm going to show you that you arewrong!

Raya: How ? By getting squashed by a bunch of spine rages?

Sisu : No, by proving to you that if we want to get someone trust, you have to givea little bit of trust first.

As Sisu has her journey with Raya, she realizes that Raya has to solve her trust issues. When they arrive at Land of Spine, she wants to show Raya how to trust someone again. 


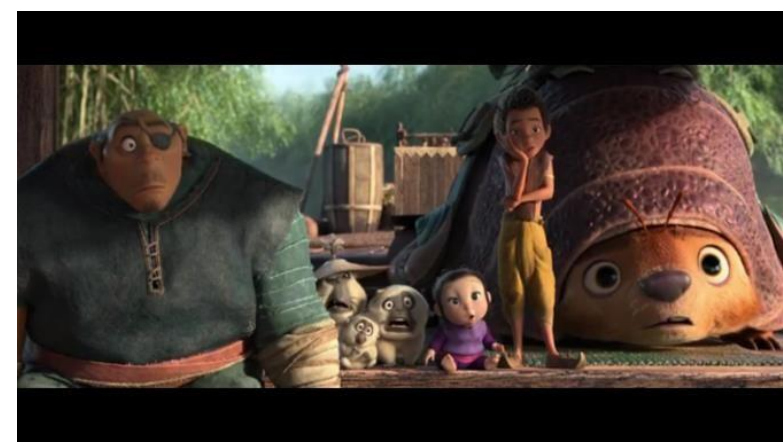

\section{(01:06:03)}

Raya and Boun plan to retrieve the last piece of gem in Fang's hands. Sisu, who is innocent and wants to teach Raya to trust people, again proposes a ridiculous idea by considering how Namaari once betrays Raya and Fang people infamous all over the land.

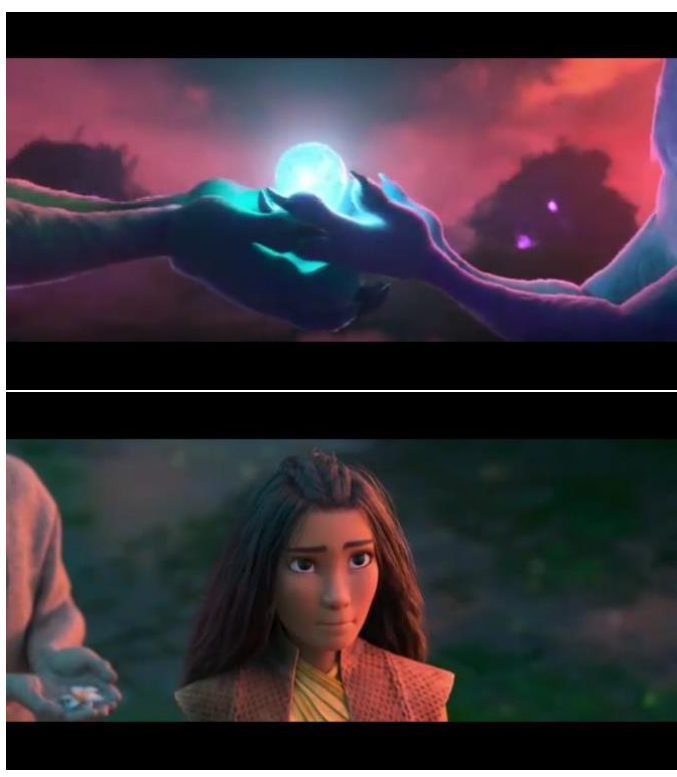

(01:08:55)-(01:10:52)
Raya : I really wish I could believe that,I once thought we could be friend
Sisu : : After all this, maybe you can be
Raya : Even if she does want to help us, how can I possibly trust her
Sisu : But if somehow you could, youwon't just bring your Ba back, you can also you also brings back his dream, Kumandra.

Sisu brings Raya to the place where her siblings rest. She tells her the story of how her siblings trust her and what impact it gives. From her expression, this makes Raya begin to consider charging someone again, especially Namaari. Even though she is not sure about it, she tries to trust others again, including those who have betrayed her. Sisu seems successful in making Raya sure that trusting each other has a good impact on their social relationship. 


\section{d. Raya's Peak of Distrust}

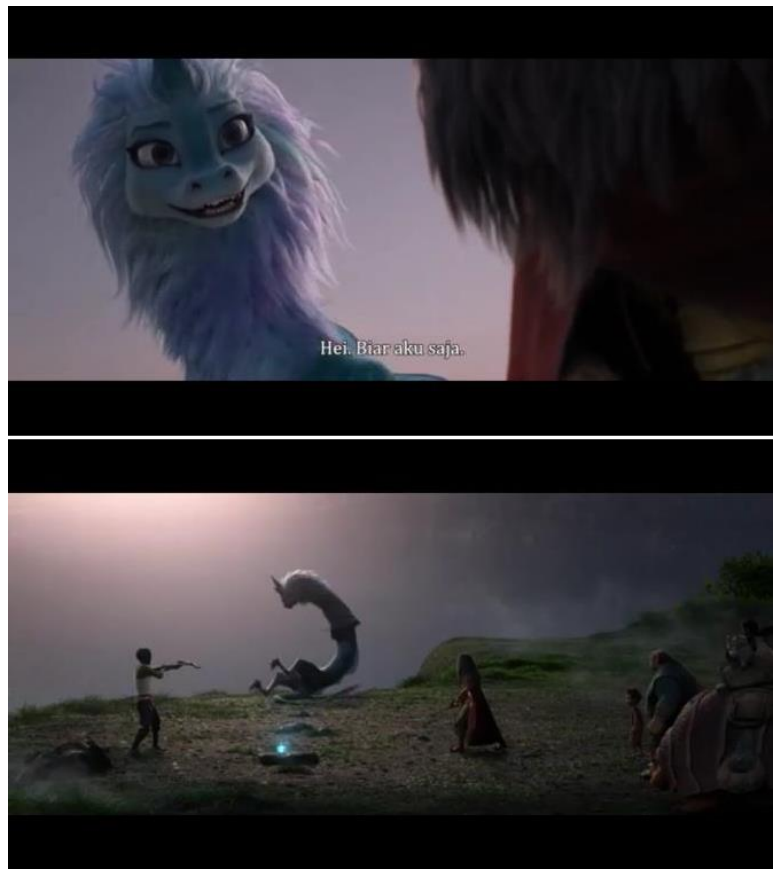

(01:17:00) -(01:17:36)

They are using Sisu's plan to give a gift to Namaari and trust her. Yet, Namaari suddenly demands that Sisu and the gem come to Fang by pointing a crossbow toward them. Raya is furious. She thinks that Namaari betrays them again. But Sisu wants Raya to trust her as she talks with Namaari. Panicked, she thinks Namaari wants to shot Sisu. Then Sisu attacks Namaari. She is shocked by Raya's attack, and accidentally, she shoots Sisu. As Sisu falls from the cliff into the water, the scared Namaari takes away one dragon gem piece.

This moment shows another trait of trust issues. Raya assumes a betrayal. Raya also does not trust Sisu. This is another sign of Raya's trust issue. She considers that a betrayal occurs again. Even she begins to distrust Sisu. She is one who Raya trusts best.

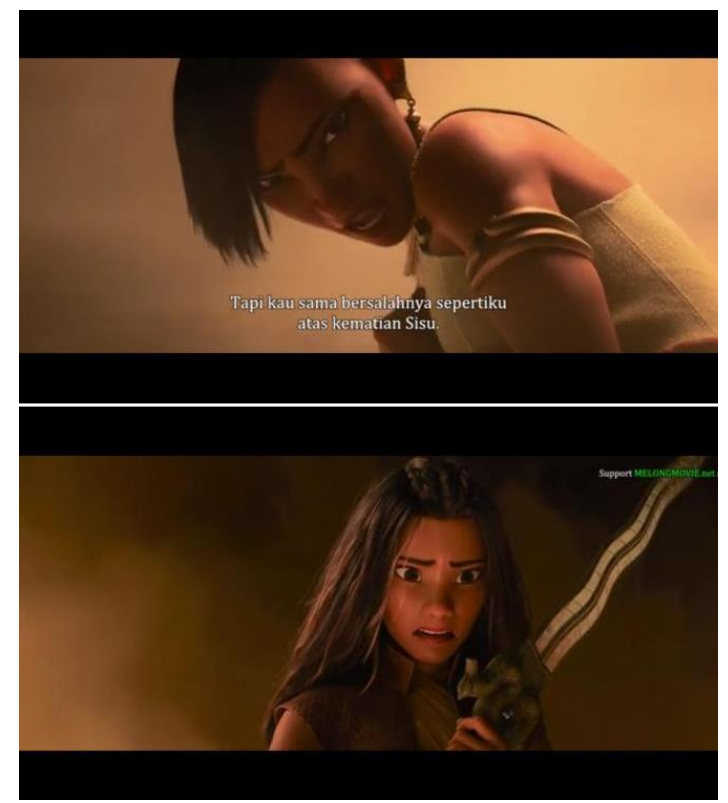

$$
\text { (01:21:42) -(01:21:49) }
$$

Namaari : ....But you didn't trust her (Sisu), that's why we're here. Do whatever you want, but you are as much to blame forSisu death as I am 
After Raya attacks Namaari to avenge Sisu, Namaari burst out that she never wants to shot Sisu. Namaari also says that Raya does not believe Sisu. Raya realizes her mistake and began to ponder as she comes into confusion.

\section{e. Raya Trusting Someone Again}

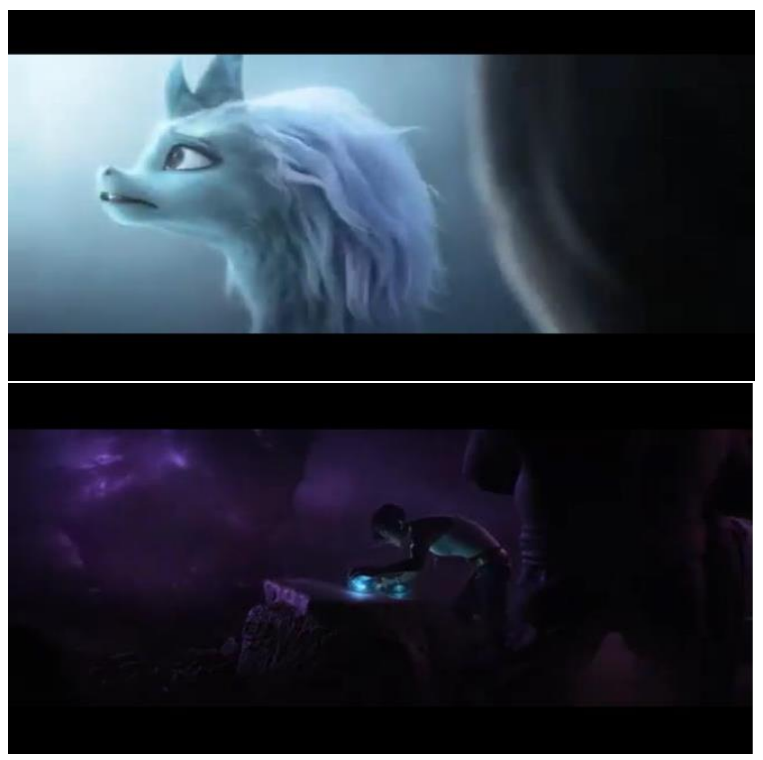

(01:23:46)- (01:26:18)

The Druun are everywhere, and they are trapped beneath some ruin. Raya suddenly remembers Sisu's word and chooses to trust the Dragon Gems to Namaari. She takes the first step to trust Namaari followed by the others. Namaari is shocked by Raya and the company's action. But seeing their sacrifices, she chooses to believe and does the uncertain. Eventually, the magic successfully happens, and they save the world.

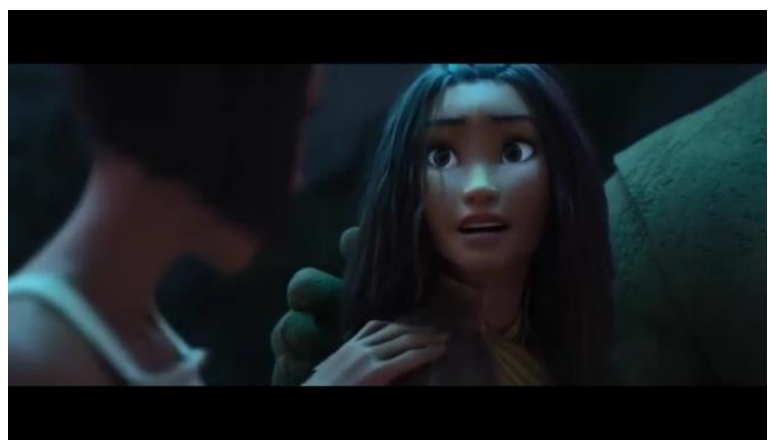

(01:28:06)

After Raya is freed from the stone and sees Namaari beside her, she is relieved that it is such magic work. She trusts Sisu's Word. When we trust others, there is a significant impact on our trust. She begins to trust Namaari. She charges that she does not take the wrong step. At the end of the movie, it is shown that Raya's trust issue has bee recovered. It is because of what has happened to her. She believes that trusting others will cause magical work.

\section{Conclusion}

It can be concluded that the protagonist in the movie shows some signs of trust issues. Her trust issue starts with betrayal. Her friend betrays her. She begins not to trust anyone, 
including her father. Her trust issue develops by other accidents. After the betrayal, she experiences trauma. She fears losing her beloved one, Sisu. She is overprotective toward Sisu. This makes her very cautious even she does not trust anyone who has served them well. She also distances herself from others. This happens because of her wariness from other people. But throughout the movie, Sisu tries a lot to overcome Raya's trust issue. She tries to teach Raya to trust the people around her. Finally, Raya succeeds in proving herself that entrusting others gives magic to a social relationship. Then, she begins to trust others.

\section{References}

Bennett, T. (2017). Do I have trust issue? Retrieved from https://thriveworks.com/blog/trust-issues/

Bierhoff, H. \& Vornefeld, B. (2004).The social psychology of trust with applications in the internet. Analyse and Kritik, 26(1) pp. 48-62

(2016). The social psychology of trust with applications in the internet. Analyse \& Kritik, 26(1), 48-62. DOI:10.1515/auk-2004-0103

Creswell, J. (2003). Research design: Qualitative, quantitative and mixed methods approaches (2nd ed.). Thousand Oaks, CA: SAGE Publications

Lau, G.T. and Lee, S.H. (1999). Consumers trust in brand and the link to brand loyalty. Journal of Market Focused Management, 4, 341-370

Lewis, M. (2013). Trust issues among children of divorce. Retrieved from http://www.drspeg.com/research/2013/divorcetrust.pdf

Goodtheraphy.org. October 8. 2014. The Psychology of Trust Issues and Ways to Overcome Them. https://www.goodtherapy.org/blog/the-psychology-of-trust-issues-and-ways-toovercome-them

Popova, M. (2014, 2 3). The Psychology of Trust in Work and Love. BrainPickings. https://www.brainpickings.org/2014/02/03/david-desteno-truth-about-trust/

Robbins, B. G. (2015). From the general to the specific: How social trust motivates relational trust. Social Science Research, 55, 16-30. http://doi.org/10.1016/j.ssresearch.2015.09.004

Soesanto, H. , and et.al. (2013). The influence of relationship closeness, service quality and religiosity on interest to saving through trust, word of mouth and attitude the study at baitul maal wat tamwil in the province of yogyakarta special region, indonesia. IOSR Journal of Business and Management, 13(3), 06-17. http://iosrjournals.org/iosr$\mathrm{jbm} /$ papers/Vol13-issue3/B01330617.pdf

Thielmann, I., and Hilbig, B.E. (2015). Trust: an integrative review from a person-situation perspective. $\quad$ Retrived on 7 July 2021 from https://www.researchgate.net/publication/275888470. DOI: 10.1037/gpr0000046

Weir, K. (2013, 12). Something's fishy. APA Monitor on Psychology. https://www.apa.org/monitor/2013/12/distrust

Zak, A. M., Gold, J. A., Ryckman, R. M., \& Lenney, E. (1998). Assessments of trust in intimate relationships and the self-perception process. The Journal of Social Psychology, 138(2), 217-228. Retrieved from http://search.proquest.com/docview/199792384?accountid=1229 